\title{
Organizational Ethical Culture, Moral Reasoning: Pengaruhnya terhadap Ethical Decision Making dan Whistleblowing Intention
}

\author{
Hidayatul Khusnah \\ Universitas Nahdlatul Ulama Surabaya \\ e-mail: hidayatul.khusnah@unusa.ac.id
}

\begin{abstract}
This study aims to investigate the factors that can encourage individuals to do whistleblowing. Factors that are predicted to affect whistleblowing intention are organizational Ethical Culture and Moral intensity and Ethical Decision Making. The sample in this study were 63 respondents. Total questionnaires distributed were 78 questionnaires, but as many as 65 questionnaires were returned, there were 2 questionnaires that were not filled out completely, so were excluded from testing. Data analysis techniques in this study used SEM-PLS. The results of this study found a positive effect of organizational ethical culture on whistleblowing intention. This shows that organizations that have a high ethical culture tend to have high whistleblowing intentions. The next finding is that moral intensity has a positive effect on ethical decision making and whistleblowing intention. This shows that individuals who have high moral intensity decisions that are made tend to be more ethical. The final finding in this research is ethical decision making which has a positive effect on whistleblowing intention. the higher the Ethical Decision Making, the higher the Whistleblowing Intention. When someone is able to make decisions ethically, it will go hand in hand with the whistleblowing intention.
\end{abstract}

Keywords: organizational ethical culture, moral reasoning, ethical decision making, whistleblowing intention

\section{PENDAHULUAN}

Beberapa tahun terakhir ini, di provinsi Jawa Timur kasus skandal keuangan semakin meningkat, baik pada sektor swasta ataupun sektor publik. Pada sektor publik, kasus skandal keuangan di Provinsi Jawa Timur terutama dengan pelaku pejabat daerah bisa dikatakan sangat tinggi (BPK.go.id). Kasus skandal keuangan di jawa timur sudah mencapai 81 kasus dan telah merugikan keuangan negara mencapai Rp4,16 M (Detik.com).

Tjahjono (2013) mengatakan hanya sekitar seperempat dari kasus fraud terungkap karena internal audit, dan seperempatnya lagi terungkap oleh adanya proses internal control atau bahkan secara tidak sengaja. Berdasarkan hal tersebut, maka peran whistleblower menjadi sangat penting untuk mengungkap tindak kecurangan yang terjadi. Dewasa ini banyak perusahaan yang tertarik dengan whistleblowing. Istilah whistleblowing erat kaitannya dengan tindakan pelaporan yang dilakukan oleh karyawan atau mantan karyawan perusahaan terkait dengan tindakan pelanggaran kepada pihak-pihak yang berwenang. Whistleblowing telah menjadi bagian integral dalam program penegakan peraturan di seluruh dunia.

Whistleblowing merupakan masalah organisasi yang kontroversial, whistleblower dapat membantu organisasi memperbaiki atau menyediakan sumber informasi yang penting dan kompleks (Near dan Miceli, 1985). Whistleblower merupakan penegak keadilan ketika terjadi suatu kesalahan dalam suatu perusahaan (Near dan Miceli, 1985). Pandangan akan whistleblower yang bertentangan, kerap menjadikan seorang 
whistleblower berada dalam situasi yang membingungkan dalam menentukan sikap yang pada akhirnya dapat melakukan whistleblowing intention.

Tindakan pengungkapan kecurangan (whistleblowing) perlu adanya keberanian, evaluasi moral dan seseorang harus menempatkan kepentingan publik dari pada kepentingan pribadinya. Saat ini, banyak whistleblower telah mengalami konsekuensi negatif termasuk kehilangan pekerjaan dan ancaman balas dendam. Namun, dengan konsekuensi tersebut, melakukan pengungkapan kecurangan merupakan sesuatu yang harus mereka lakukan sebagai bentuk dalam melindungi organisasi mereka dari ancaman yang dapat membahayakan perusahaan. Tindakan whistleblowing tidak dimaksudkan untuk menyebabkan bahaya tetapi untuk melindungi, mencegah penipuan dan kesalahan (Zakaria, 2015).

Penelitian ini bertujuan untuk menginvestigasi faktor-faktor yang dapat mendorong individu untuk melakukan whistleblowing. Faktorfaktor yang diprediksi dapat memengaruhi whistleblowing intention adalah organizational ethical culture dan moral reasoning dan ethical decision making. Beberapa penelitian terdahulu telah memprediksi bahwa organizational ethical culture adalah faktor antecedent dari whistleblowing intention (Keenan, 1990; Rothwell dan Baldwin, 2006; Hwang et al., 2013; Zakaria, 2018). Organizational ethical culture dikonseptualisasikan sebagai persepsi karyawan tentang sejauh mana komitmen organisasi dalam kaitannya dengan masalah etika terhadap karyawan dan manajemennya (Victor dan Culen, 1988). Organisasi yang memiliki nilai etika tinggi maka karyawan akan merasa bahwa selalu didukung ketika akan melakukan hal-hal yang terpuji, salah satunya whistleblowing, hal tersebut akan mendorong lebih banyak lagi niat karyawan untuk melakukan whistleblowing.
Faktor kedua yang diprediksi memiliki dampak terhadap whistleblowing intention adalah moral intention. Moral reasoning atau intensitas moral adalah tingkatan kuat atau lemahnya perasaan dalam melakukan suatu perbuatan. Intensitas moral dapat berhubungan dengan persepsi kontrol perilaku yang tecermin dalam teori perilaku yang terencana (theory of planned behavior) yaitu persepsi yang dimiliki oleh seseorang yang merupakan hasil dari kontrol diri seseorang dalam melakukan suatu tindakan (Krehastuti dan Prastiwi, 2014).

Beberapa penelitian sebelumnya yang ada di Indonesia juga mengaitkan faktor moral reasoning dengan whistleblowing intention. Fidyawati (2016), Krehastuti dan Prastiwi (2014) melakukan penelitian mengenai pengaruh intensitas moral terhadap niat untuk menjadi whistleblower. Hasil penelitian menunjukkan bahwa intensitas moral berpengaruh terhadap niat untuk menjadi whistleblower. Hal tersebut tidak didukung oleh penelitian yang dilakukan Ahyaruddin dan Asnawi (2017) yang menyatakan bahwa moral individu dan lingkungan etis organisasi tidak berpengaruh terhadap kecenderungan individu untuk melakukan whistleblowing pada auditor BPKB perwakilan provinsi Riau.

Penelitian ini diharapkan akan dapat memberikan sumbangan konseptual dalam literatur khususnya di bidang akuntansi serta memberikan kontribusi praktis bagi organisasi terutama di sektor publik untuk melakukan upaya-upaya dalam rangka mengurangi kecurangan yang terjadi serta memberikan fasilitas kepada whistleblower untuk mengungkap kecurangan tersebut tanpa ada rasa takut.

Sampel dalam penelitian ini sebanyak 63 responden. Total kuesioner yang disebar adalah 78 kuesioner, akan tetapi yang kembali sebanyak 65 kuesioner, terdapat 2 kuesioner yang tidak diisi dengan lengkap, sehingga dikeluarkan dari 
pengujian. Teknik analisis data dalam penelitian ini menggunakan SEM-PLS. Hasil penelitian ini menemukan pengaruh positif dari organizational ethical culture terhadap whistleblowing intention. Hal tersebut menunjukkan bahwa organisasi yang memiliki budaya etika yang tinggi maka cenderung memiliki niat untuk melakukan whistleblowing yang tinggi juga. Temuan selanjutnya yaitu moral reasoning berpengaruh positif terhadap ethical decision making dan whistleblowing intention. Hal tersebut menunjukkan bahwa individu yang memiliki intensitas moral yang tinggi keputusan yang diambil cenderung akan lebih beretika. Temuan terakhir dalam penelitian ini yaitu ethical decision making berpengaruh positif terhadap whistleblowing intention. semakin tinggi Ethical Decision Making maka semakin tinggi pula whistleblowing Intention. Ketika seseorang mampu mengambil keputusan dengan etis, maka akan beriringan positif dengan niat untuk melakukan whistleblowing.

\section{Landasan Teori dan Pengembangan Hipotesis}

Istilah whistleblowing sudah banyak didefinisikan oleh beberapa peneliti terdahulu, salah satunya yaitu Near \& Miceli (1985), McLain \& Keenan (1999) mendefinisikan whistleblowing sebagai pengungkapan oleh anggota organisasi (anggota yang masih berada dalam organisasi maupun yang sudah keluar dari organisasi) terkait dengan praktik ilegal, tidak bermoral, atau praktik yang tidak dapat dilegitimasi secara hukum di bawah kontrol majikan mereka, kepada orang ataupun organisasi yang mungkin mampu untuk memengaruhi suatu tindakan.

Whistleblowing dianggap menjadi alat yang berharga dalam strategi tata kelola perusahaan (corporate governance), sebagai suatu pelaporan pelanggaran yang dapat membantu menjaga keamanan tempat kerja, sekaligus melindungi keun- tungan dan reputasi perusahaan (Susmanschi, 2012). Orang atau pihak yang melihat beberapa tindakan yang salah dan melaporkan tindakan tersebut kepada manajemen atau regulator (pemerintah) disebut whistleblower. Whistleblower merupakan salah satu sumber yang penting dalam pengungkapan kecurangan (fraud). Hal ini karena whistleblower yang menjadi salah satu bagian dari internal organisasi merupakan pihak yang paling tahu mengenai terjadinya fraud di dalam organisasi.

Victor dan Cullen (1988) mengonseptualisasikan organizational ethical culture sebagai persepsi karyawan tentang sejauh mana komitmen organisasi dalam kaitannya dengan masalah etika terhadap karyawan dan manajemennya. Marta (1999) menegaskan bahwa organizational ethical culture diciptakan dalam organisasi melalui praktik manajemen kebijakan etika, penegakan dan tindakan. Fang (2006), budaya etis organisasi menciptakan dan menanamkan keyakinan etis di antara anggotanya tentang apa yang dirasakan oleh anggota organisasi mereka akan meningkatkan kewajiban moral mereka untuk melindungi kepentingan organisasi yang mereka layani. Sebagai imbalannya, organisasi harus mendukung tindakan mulia anggota melalui penghargaan dan saluran pelaporan birokrasi yang lebih sedikit.

Organizational ethical culture dapat sangat memengaruhi niat pengungkap fakta. Manajemen organisasi bertanggung jawab atas budaya etika yang sehat dan dengan demikian mencerminkan komitmen etis manajemen (Mendonca, 2011) dalam mendorong niat anggota untuk melakukan whistleblowing penting bahwa baik manajemen dan anggota memainkan peran penting dalam memperkuat dan memperkuat perlindungan terhadap whistle-blower. Oleh karena itu, budaya etika yang sehat dan perlindungan yang diberikan kepada whistle-blower akan 
merangsang kemungkinan whistleblowing intention di antara anggota.

\section{Organizational Ethical Culture dengan Whistle- blowing Intention}

Organizational ethical culture menciptakan dan menanamkan keyakinan etis di antara anggota organisasi, lingkungan etis yang kuat dapat membantu mengurangi kecenderungan manajer untuk berperilaku oportunistik ketika terdapat masalah agensi (agency problems) (Booth \& Schulz, 2004). Menciptakan sebuah lingkungan etis yang kuat dapat menjadi pilihan pengendalian yang sangat diharapkan bagi organisasi secara umum (Akhyarudin dan Asnawi, 2017). budaya organisasi yang etis akan meningkatkan moral seseorang sehingga dapat mendorong niat seseorang untuk melaporkan ketika terjadi tidak kecurangan, maka dari itu hipotesis yang diajukan dalam penelitian ini adalah sebagai berikut. H1: Organizational ethical culture berpengaruh positif terhadap whistleblowing intention

\section{Moral Reasoning, Ethical Decision Making, dan Whistleblowing Intention}

Ethical decision making atau pengambilan keputusan etis terjadi ketika seseorang dalam kondisi dilema etika di tempat kerja (Jones, 1991). Pengambilan keputusan etis dipengaruhi oleh faktor eksternal (lingkungan) dan internal individu itu sendiri (O'Fallon dan Butterfield, 2005; Craft, 2013). Jones (1991) mengatakan bahwa moral reasoning memengaruhi penalaran seseorang. Semakin tinggi moral reasoning seseorang maka penalaran yang ia lakukan juga semakin lebih baik. Penelitian sebelumnya yang mengaitkan moral reasoning dengan pengambilan keputusan etis (Cohen dan Bennie 2006; Har- rington, 1997; Mei dan Pauli, 2002; Valentine dan Godkin, 2019). Berdasarkan hal tersebut, maka hipotesis yang dirumuskan adalah sebagai berikut.

$\mathrm{H} 2$ : Moral reasoning berpengaruh positif terhadap ethical decision making

Salah satu faktor penting yang memengaruhi keputusan individu untuk melakukan whistleblowing adalah perilaku moral (Near \& Miceli,1995). Keputusan seseorang memutuskan untuk melakukan whistleblowing dipengaruhi oleh beberapa hal, yakni karakter pribadi individu, lingkungan sekitar serta ketakutan adanya pembalasan (Near \& Miceli, 1995). Individu yang memiliki penalaran moral yang lebih tinggi memiliki kecenderungan untuk melakukan whistleblowing dibandingkan dengan individu yang memiliki penalaran moral yang lebih rendah (Liyanarachchi \& Newdick, 2009). Semakin tinggi penalaran moral individu, maka kecenderungan untuk mengungkapkan tindak kecurangan yang terjadi juga semakin tinggi, maka dari itu hipotesis dalam penelitian ini adalah sebagai berikut.

H3: Moral reasoning berpengaruh positif terhadap whistleblowing intention

\section{Ethical Decision Making dengan Whistleblowing Intention}

Whistleblowing yaitu tindakan oleh seorang karyawan, mantan karyawan atau anggota organisasi untuk melaporkan tindak kecurangan oleh seseorang atau sekelompok orang yang berdampak terhadap masyarakat umum (Shawver, 2011). Akan tetapi, niat seseorang untuk melakukan whistleblowing sering kali hilang ketika dihadapkan pada ancaman pembalasan di masa yang akan datang. hal tersebut tidak berlaku ketika 


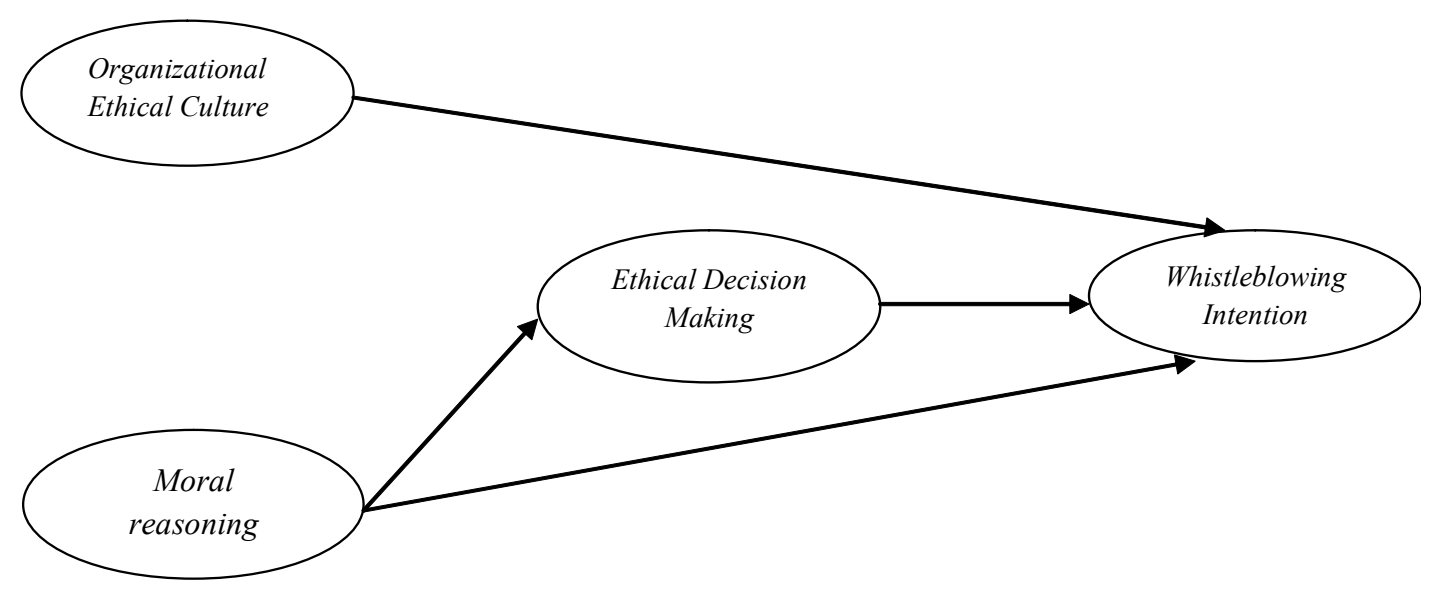

Gambar 1.1 Desain Penelitian

seseorang tersebut memiliki penalaran moral yang tinggi. Valentine dan Godkin (2019) menggabungkan faktor individu, organisasi dan sosial untuk mendorong niat seseorang lam melakukan whistleblowing. Faktor yang diusulkan tersebut adalah ethical decision making atau pengambilan keputusan etis.

Pengambilan keputusan etis terjadi ketika seseorang dalam kondisi dilema etika di tempat kerja (Jones, 1991). Ketika seseorang berniat melakukan sesuatu maka seseorang tersebut harus memahami terlebih dahulu situasi yang ada, apakah memiliki implikasi etis atau tidak (Trevino, 1986; Rest, 1986; Jones, 1991). Ketika seseorang mampu mengambil keputusan dengan etis, maka akan beriringan positif dengan niat untuk melakukan whistleblowing. Berdasarkan hal tersebut, maka hipotesis yang diajukan adalah sebagai berikut.

H4: Ethical decision making berpengaruh positif dengan whistleblowing intention

\section{METODE PENELITIAN}

\section{Sampel Penelitian dan Teknik Pengumpulan Data}

Sampel dalam penelitian ini adalah Manajer Akuntansi atau Manajer Keuangan Perusahaan
Manufaktur di kawasan PT Surabaya Industrial Estate (SIER) yang terdaftar dalam Buku Daftar Investor Tahun 2017. Pemilihan sampel pada satu jenis industri diharapkan dapat mengurangi kemungkinan industry effect terhadap data yang dianalisis. Teknik pengambilan sampel dalam penelitian ini menggunakan metode purposive sampling. Adapun kriteria penentuan sampel yang digunakan dalam penelitian ini adalah sebagai berikut.

1. Bekerja di perusahaan manufaktur yang terdaftar dalam Buku Daftar Investor/Investor Guidance Book (2017) di kawasan industri SIER.

2. Mempunyai jabatan sebagai manajer akuntansi atau manajer keuangan.

3. Bekerja minimal selama satu tahun. Manajer akuntansi atau manajer keuangan yang bekerja selama satu tahun dianggap sudah memenuhi kualifikasi mengenai pengetahuan terhadap lingkungan perusahaan dengan baik sehingga bisa menilai bagaimana perusahaan dalam menangani kecenderungan kecurangan akuntansi.

Data dalam penelitian ini diperoleh dengan menyebarkan kuesioner langsung kepada Manajer Akuntansi atau Manajer Keuangan Perusahaan 
Manufaktur di kawasan PT Surabaya Industrial Estate (SIER). Penelitian ini menggunakan kuesioner cetak yang diantar langsung ke Perusahaan Manufaktur di kawasan PT Surabaya Industrial Estate (SIER).

Jumlah kuesioner yang disebar sebanyak 78 kuesioner dan yang kembali sebanyak 65 kuesioner. Berdasarkan data yang terkumpul, terdapat 2 kuesioner yang tidak diisi dengan lengkap sehingga total kuesioner yang dapat diolah sebanyak 63. Persentase tingkat respons dalam penelitian ini sebesar $81 \%$, jumlah persentase tersebut menunjukkan bahwa tingkat respons dari responden sangat tinggi.

\section{Pengukuran Variabel}

Variabel organizational ethical culture diukur menggunakan instrumen yang dikembangkan oleh Hunt et al. (1989) yang digunakan oleh Falah (2006) dan Nurfarida (2011) yang setiap item pertanyaan berisi tentang tindakantindakan yang dilakukan pimpinan terhadap bawahannya pada tindakan etis maupun tidak etis yang berhubungan dengan whistleblowing intention. Variabel organizational ethical culture diukur menggunakan lima pertanyaan.

Variabel moral reasoning diukur menggunakan instrumen yang dikembangkan oleh Jones (1991). Instrumen tersebut diukur dengan menggunakan enam pernyataan dengan menggunakan skala likert 5 (lima) point. Variabel Ethical decision making diukur menggunakan 8 (delapan) item pernyataan, yang terdiri dari 4 (empat) item yang didasarkan pada persepsi individu tentang situasi yang disorot dalam skenario etika, sedangkan 4 (empat) item pernyataan penilaian etis yang dinilai dengan skala "moral equity" yang menunjukkan sejauh mana responden percaya bahwa situasi benar-benar tidak etis (Valentine and Godkin, 2019).
Variabel whistleblowing intention dalam penelitian ini diukur menggunakan instrumen dari Liyanarachchi \& Newdick (2009) yang digunakan oleh peneliti di Indonesia Ahyaruddin dan Asnawi (2017), Pratiwi (2015), Abdilla (2017), dan Rodiyah (2014). Whistleblowing intention dalam penelitian ini menggunakan 5 item pertanyaan.

\section{Hasil}

Analisis data dan pengujian hipotesis dalam penelitian ini menggunakan structural equation modeling (SEM) dengan metoda alternatif partial least square (PLS) dengan menggunakan software WarpPLS 3.0. Ada dua tahap dalam pengujian menggunakan SEM-PLS, yaitu analisis model pengukuran dan analisis model struktural. Tahap pertama yang dilakukan adalah mengevaluasi model pengukuran terlebih dahulu, setelah itu baru mengevaluasi model struktural.

Proses perancangan model struktural dalam penelitian ini dengan menggunakan tujuh konstruk (variabel laten). Konstruk tersebut terdiri dari satu konstruk eksogen dan enam konstruk endogen. Konstruk yang ada di dalam model struktural masing-masing memiliki indikator yang berfungsi sebagai alat ukur untuk indikator tersebut.

Evaluasi model pengukuran bertujuan untuk mengetahui kualitas dari alat ukur (instrumen) dari sebuah konstruk. Terdapat dua pendekatan untuk mengukur konstruk dalam evaluasi model pengukuran, yaitu pengukuran reflektif dan pengukuran formatif. Penelitian ini hanya menggunakan satu pendekatan saja yaitu pendekatan pengukuran reflektif. Konstruk reflektif dinilai berdasarkan nilai cross loading masing-masing konstruk. Uji validitas dalam model pengukuran terdiri dari dua parameter, yaitu validitas konvergen dan validitas diskriminan. 
Uji validitas konvergen didasarkan pada faktor loading masing-masing indikator dari konstruk yang mana loading indikator lebih besar dari 0.70, sedangkan untuk uji validitas diskriminan dinilai dengan cara membandingkan akar kuadrat dari average variance extracted (AVE) dengan korelasi antar konstruk, atau bisa juga dengan cara membandingkan loading konstruk yang diukur dengan loading konstruk yang lainnya (Sholihin dan Ratmono, 2013). Pengujian reliabilitas diukur menggunakan composite reliability dan cronbach alpha. Rule of thumb dari composite reliability dan cronbach alpha adalah lebih besar dari 0,70 (Sholihin dan Ratmono, 2013).

Validitas konvergen berhubungan dengan prinsip bahwa pengukur-pengukur dari suatu konstruk seharusnya berkorelasi tinggi (Hartono dan Abdillah, 2014). Uji validitas konvergen

Tabel 1.1 Nilai Loading Kombinasi dan Faktor Loading

\begin{tabular}{|l|c|c|c|}
\hline Variabel & Item & Loading & P-Value \\
\hline $\begin{array}{l}\text { Organizational } \\
\text { Ethical Culture } \\
\text { (OEC) }\end{array}$ & OEC1 & 0,712 & $<0,001$ \\
\cline { 2 - 4 } & OEC2 & 0,844 & $<0,001$ \\
\cline { 2 - 4 } & OEC3 & 0,851 & $<0,001$ \\
\cline { 2 - 4 } & OEC4 & 0,846 & $<0,001$ \\
\cline { 2 - 4 } & OEC5 & $\mathbf{0 , 5 8 3}$ & $<0,001$ \\
\hline \multirow{4}{*}{$\begin{array}{l}\text { Moral reasoning } \\
\text { (MI) }\end{array}$} & MI1 & 0,656 & $<0,001$ \\
\cline { 2 - 4 } & MI2 & 0,724 & $<0,001$ \\
\cline { 2 - 4 } & MI3 & 0,693 & $<0,001$ \\
\cline { 2 - 4 } & MI4 & $-\mathbf{0 , 6 0 9}$ & $<0,001$ \\
\cline { 2 - 4 } & MI5 & $-0,685$ & $<0,001$ \\
\cline { 2 - 4 } & MI6 & $-0,738$ & $<0,001$ \\
\hline \multirow{4}{*}{$\begin{array}{l}\text { Ethical Decision } \\
\text { Making (EDM) }\end{array}$} & EDM1 & 0,788 & $<0,001$ \\
\cline { 2 - 4 } & EDM2 & 0,866 & $<0,001$ \\
\cline { 2 - 4 } & EDM3 & 0,768 & $<0,001$ \\
\cline { 2 - 4 } & EDM4 & 0,828 & $<0,001$ \\
\cline { 2 - 4 } & EDM5 & 0,829 & $<0,001$ \\
\cline { 2 - 4 } & EDM6 & 0,682 & $<0,001$ \\
\cline { 2 - 4 } & EDM7 & 0,838 & $<0,001$ \\
\cline { 2 - 4 } & EDM8 & 0,768 & $<0,001$ \\
\hline \multirow{4}{*}{\begin{tabular}{l} 
Intention (WI) \\
\cline { 2 - 4 }
\end{tabular}} & WI1 & 0,758 & $<0,001$ \\
\cline { 2 - 4 } & WI2 & 0,851 & $<0,001$ \\
\cline { 2 - 4 } & WI3 & 0,815 & $<0,001$ \\
\cline { 2 - 4 } & WI4 & 0,785 & $<0,001$ \\
\hline \multirow{4}{*}{ WI5 } & 0,772 & $<0,001$ \\
\hline
\end{tabular}

dinilai berdasarkan pada faktor loading masingmasing konstruk lebih besar dari 0.70 (Sholihin dan Ratmono, 2013).

Tabel 1.1 menyajikan hasil uji validitas konvergen masing-masing konstruk. Hasil dari uji validitas konvergen tersebut menunjukkan ada beberapa indikator dari beberapa konstruk ada yang memiliki nilai faktor loading di bawah 0,7. Beberapa indikator tersebut yang dicetak tebal di dalam tabel di atas. Untuk P-Value masingmasing indikator telah memenuhi kriteria, yaitu kurang dari 0,05 . Indikator-indikator yang memiliki nilai faktor loading kurang dari 0,7 tidak dimasukkan dalam pengolahan data karena dianggap tidak memenuhi kriteria validitas konvergen.

Pengujian selanjutnya adalah uji validitas diskriminan. Uji validitas diskriminan dinilai dengan cara membandingkan akar kuadrat dari average variance extracted (AVE) dengan korelasi antar-konstruk, atau bisa juga dengan cara membandingkan loading konstruk yang diukur dengan loading konstruk yang lainnya (Sholihin dan Ratmono, 2013).

Tabel 1.2 Korelasi antar-Variabel Laten

\begin{tabular}{|l|c|c|c|c|}
\hline & OEC & MI & EDM & WI \\
\hline OEC & $\mathbf{0 , 5 2 8}$ & 0,422 & 0,285 & 0,326 \\
\hline MI & 0,422 & $\mathbf{0 , 4 7 6}$ & 0,378 & 0,328 \\
\hline EDM & 0,285 & 0,378 & $\mathbf{0 , 5 5 4}$ & 0,240 \\
\hline WI & 0,326 & 0,328 & 0,240 & $\mathbf{0 , 5 5 3}$ \\
\hline
\end{tabular}

Tabel 1.2 menyajikan hasil pengujian validitas diskriminan dari konstruk dalam penelitian ini. Hasil pada tabel di atas menunjukkan bahwa validitas diskriminan dalam penelitian ini telah terpenuhi dilihat dari nilai akar kuadrat dari AVE pada kolom diagonal lebih besar dari pada korelasi antarkonstruk pada kolom yang sama.

Pengujian selanjutnya Pengujian reliabilitas diukur menggunakan composite reliability dan 
cronbach alpha. Rule of thumb dari composite reliability dan cronbach's alpha adalah lebih besar dari 0,70 (Sholihin dan Ratmono, 2013). Hasil pengujian reliabilitas konsistensi internal dalam penelitian ini disajikan dalam Tabel 1.3.

\section{Tabel 1.3 Hasil Uji Reliabilitas Konsistensi Internal}

\begin{tabular}{|l|c|c|c|c|}
\hline \multicolumn{1}{|c|}{ Koefisien } & OEC & MI & EDM & WI \\
\hline Composite reliability & 0,869 & 0,001 & 0,933 & 0,897 \\
\hline Cronbach's alpha & 0,806 & 0,374 & 0,917 & 0,856 \\
\hline AVE & 0,579 & 0,470 & 0,636 & 0,635 \\
\hline
\end{tabular}

Pengujian selanjutnya adalah evaluasi model struktural. Evaluasi model struktural dalam SEM-PLS dengan menggunakan nilai koefisien determinasi $\left(\mathrm{R}^{2}\right)$ dan nilai Q-Squared. Berikut adalah hasil pengujian evaluasi model struktural yang tersaji dalam Tabel 1.4.

Tabel 1.4 Koefisien Variabel Laten

\begin{tabular}{|l|c|c|c|c|}
\hline \multicolumn{1}{|c|}{ Koefisien } & OEC & MI & EDM & WI \\
\hline $\mathrm{R}^{2}$ & & & 0,290 & 0,332 \\
\hline Q-Squared & & & 0,307 & 0,370 \\
\hline
\end{tabular}

Penelitian ini mengajukan empat hipotesis. Hipotesis dalam penelitian ini dikatakan terdukung apabila memiliki nilai $p$-value $<0,01$ (signifikan pada tingkat $1 \%$ ), p-value $<0,05$ (signifikan pada level 5\%) dan p-value $<0,1$ (signifikan pada level 10\%). Gambar 1.2 menunjukkan hasil pengujian hipotesis dalam penelitian ini.

\section{Organizational Ethical Culture dengan Whistle- blowing Intention}

Hasil pengujian hipotesis yang disajikan dalam Gambar 1.2 menunjukkan nilai p-value dan koefisien jalur organizational ethical culture (OEC) terhadap whistleblowing intention (WI) sebesar 0,002 dan 0,113 (signifikan pada level 1\%). Hasil tersebut menunjukkan bahwa Hipotesis 1 terdukung. Semakin tinggi budaya etika dalam suatu organisasi maka kecenderungan keinginan untuk melakukan whistleblowing juga tinggi. hasil penelitian ini sesuai dengan argumen yang ditulis dalam penelitian (Zakaria, 2015).

\section{Moral Reasoning, Ethical Decision Making dan Whistleblowing Intention}

Hasil pengujian hipotesis berikutnya adalah pengaruh moral reasoning terhadap ethical decision making. Berdasarkan hasil pengujian yang tertera dalam gambar di atas menunjukkan $p$ value dan nilai koefisien jalur sebesar $<0,001$ dan 0,376. Berdasarkan hasil tersebut maka hipotesis 2 terdukung. Semakin tinggi moral

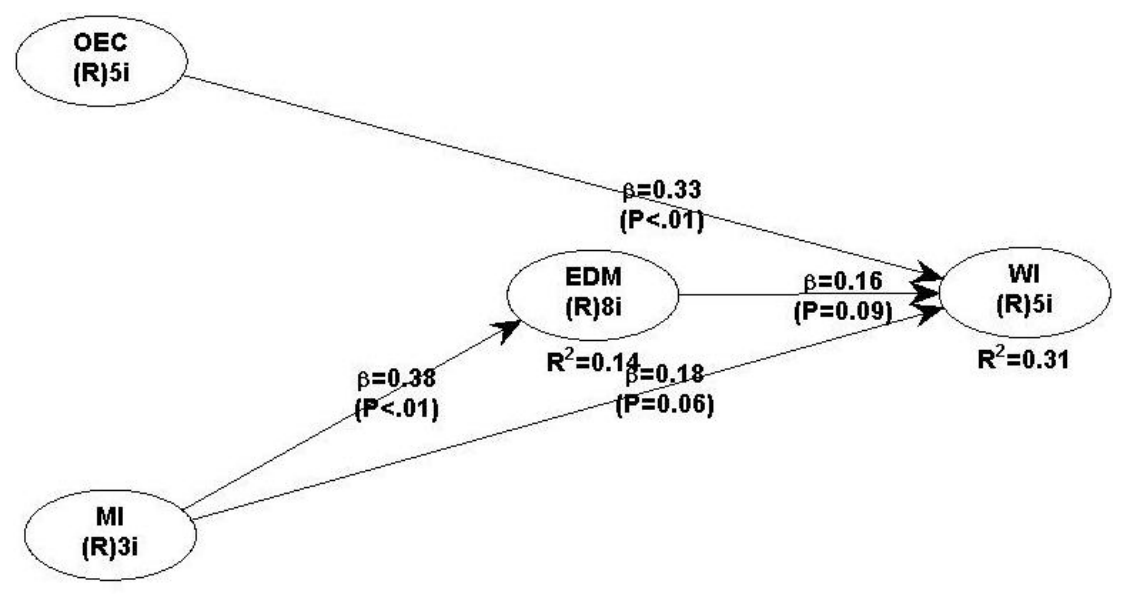

Gambar 1.2 Hasil Pengujian Hipotesis 
intensiti individu maka semakin tinggi pula pengambilan keputusan etisnya. Moral reasoning memengaruhi penalaran seseorang. Semakin tinggi moral reasoning seseorang maka penalaran yang ia lakukan juga semakin lebih baik (Jones, 1991). Hasil penelitian ini sesuai dengan penelitian yang dilakukan oleh penelitian sebelumnya (Cohen dan Bennie 2006; Harrington, 1997; Mei dan Pauli, 2002; Valentine dan Godkin, 2019).

Hipotesis ketiga yaitu Moral reasoning berpengaruh positif terhadap whistleblowing intention. Berdasarkan hasil pengujian hipotesis dapat diketahui $p$-value dan nilai koefisien jalurnya sebesar 0,063 dan 0,184 (signifikan pada level 10\%) sehingga hipotesis 3 terdukung. Semakin tinggi penalaran moral individu maka semakin tinggi pula niat untuk melakukan whistleblowing. Individu yang memiliki penalaran moral yang lebih tinggi memiliki kecenderungan untuk melakukan whistleblowing dibandingkan dengan individu yang memiliki penalaran moral yang lebih rendah (Liyanarachchi \& Newdick, 2009).

\section{Ethical Decision Making dengan Whistleblowing Intention}

Hipotesis terakhir yang diajukan dalam penelitian ini adalah ethical decision making berhubungan positif dengan whistleblowing Intention. Berdasarkan pengujian hipotesis yang telah dilakukan diketahui $p$-value dan nilai koefisien jalurnya adalah sebesar 0,086 dan 0,164 (signifikan pada level 10\%) sehingga hipotesis 4 diterima. Hal tersebut dapat diartikan bahwa semakin tinggi Ethical Decision Making maka semakin tinggi pula whistleblowing Intention. Ketika seseorang mampu mengambil keputusan dengan etis, maka akan beriringan positif dengan niat untuk melakukan whistleblowing.

\section{KESIMPULAN}

Penelitian ini bertujuan untuk menginvestigasi faktor-faktor yang dapat mendorong individu untuk melakukan whistleblowing. Faktorfaktor yang diprediksi dapat memengaruhi whistleblowing intention adalah organizational ethical culture dan moral reasoning dan ethical decision making.

Hasil penelitian ini menunjukkan pengaruh positif dari organizational ethical culture terhadap whistleblowing intention. Berdasarkan hasil tersebut dapat disimpulkan bahwa semakin tinggi budaya etika dalam suatu organisasi maka kecenderungan keinginan untuk melakukan whistleblowing juga tinggi. Individu yang berada pada lingkungan organisasi yang memiliki budaya etika tinggi cenderung melakukan apa pun sesuai dengan etika yang berlaku. Salah satunya ketika melihat adanya tindak kecurangan, maka individu tersebut cenderung memiliki niat yang lebih tinggi untuk melaporkan tindakan tersebut.

Penelitian ini juga menemukan pengaruh positif dari moral reasoning terhadap ethical decision making. Moral reasoning memengaruhi penalaran moral seseorang. Semakin tinggi moral reasoning seseorang maka penalaran yang ia lakukan juga semakin lebih baik (Jones, 1991). Semakin baik penalaran moral seseorang maka keputusan yang akan diambil cenderung keputusan yang tidak keluar dari aturan yang berlaku. Selain menemukan pengaruh positif dari moral reasoning terhadap ethical decision making, penelitian ini juga menemukan pengaruh positif dari moral reasoning terhadap whistleblowing intention. Ketika seseorang memiliki penalaran moral yang baik atau tinggi maka cenderung akan melakukan hal-hal yang baik dan meninggalkan atau menjauhi hal-hal yang bertentangan dengan etika. Seseorang dengan tingkat moral yang tinggi ketika melihat tindak kecurangan yang dilakukan 
oleh orang lain cenderung berniat untuk melaporkan tindakan tersebut. Semakin tinggi moral reasoning seseorang maka semakin tinggi pula whistleblowing intention.

Temuan terakhir dalam penelitian ini yaitu Ethical decision making berpengaruh positif terhadap whistleblowing intention. Ketika seseorang mampu mengambil keputusan yang tidak bertentangan dengan etika yang ada maka dia juga mampu mengungkap tindakan-tindakan yang berlawanan dengan etika. Semakin tinggi ethical decision making seseorang maka semakin tinggi pula whistleblowing intention.

Berdasarkan keseluruhan hasil penelitian ini dapat disimpulkan bahwa etika itu sangat penting, baik dari lingkungan sekitar maupun dari diri seseorang itu sendiri. Seseorang yang berada dalam lingkungan organisasi yang memiliki budaya etika yang tinggi serta memiliki moralitas yang tinggi pula cenderung akan melakukan hal-hal yang sesuai dengan aturan dan norma yang berlaku. Termasuk salah satunya adalah niat untuk melaporkan tindak kecurangan yang dilakukan oleh orang lain.

\section{DAFTAR RUJUKAN}

Ahyaruddin, M. \& Asnawi, M. 2017. "Pengaruh Moral Reasoning dan Ethical Environment Terhadap Kecenderungan untuk Melakukan Whistleblowing”. Jurnal Akuntansi \& Ekonomika, Vol. 1.

Booth, P. \& Schulz, A.K.-D. 2004. The Impact of an Ethical Environment on Managers' Project Evaluation Judgments under Agency Problem Conditions. Accounting, Organizations and Society, 29(5-6), 473488.

Cohen, J.R. \& Bennie, N.M. 2006. The Applicability of a Contingent Factors Model to
Accounting Ethics Research. Journal of Business Ethics, 68(1), 1-18.

Craft, J. 2013. A Review of the Empirical Ethical Decision-Making Literature: 20042011. Journal of Business Ethics, 117(2), 221-259.

Fang, M.L. 2006. Evaluating Ethical DecisionMaking of Individual Employees in Organizations - An Integration Framework. Journal of American Academy of Business, 8(2), 105-113.

Fleischman, G.M., Valentine, S., \& Finn, D.W. 2007. Ethical Reasoning and Equitable Relief. Behavioral Research in Accounting, 19, 107-132.

Harrington, S.J. 1997. A Test of a Person-Issue Contingent Model of Ethical Decisionmaking in Organizations. Journal of Business Ethics, 16, 363-375.

Hartono, J., and Abdillah, W. 2014. Konsep and Aplikasi PLS (Partial Least Square) untuk Penelitian Empiris. Edisi pertama. Yogyakarta: BPFE.

Hwang, D.B.K, Staley, A.B., Tsai, Y., \& Chui, C.L., 2013. A Comparative Study of the Propensity of Whistle-Blowing Empirical Evidence from China, Taiwan and the United States. International Journal of Accounting and Financial Reporting, 3 (2), 202-204.

Jones, T. 1991. Ethical Decision Making by Individuals in Organizations: An IssueContingent Model. Academy of Management Review, 16(2), 366-395.

Keenan, J.P. 1990. Upper-Level Managers and Whistleblowing: Determinants of Perceptions of Company Encouragement and Information about Where to Blow the Whistle. Journal of Business and Psychology, 5 (2), 223-235. 
Keenan, J.P. 2000. Blowing the Whistle on Less Serious Forms of Fraud: A Study of Executives and Managers. Employee Responsibilities and Rights Journal, 12 (4), 199217.

Kreshastuti, D.K. dan Prastiwi, A. 2014. Analisis Faktor-Faktor yang Mempengaruhi Intensi Auditor untuk Melakukan Tindakan Whistleblowing (Studi Empiris pada Kantor Akuntan Publik di Semarang). Diponegoro Journal of Accounting, Vol. 3, No. 2, pp. 2-8.

Liyanarachchi, G. \& Newdick, C. 2009. The Impact of Moral Intensity and Retaliation on Whistle-Blowing: New Zealand Evidence. Journal of Business Ethics, 89(1), 37-57.

Marta, J.K.M. 1999. An Empirical Investigation into Significant Factors of Moral intensity and their Influences on Ethical Judgments and Intentions. Doctoral dissertation, Old Dominion University. (UMI No: 9928703). Retrieved May, 24, 2006 from http:// www.proquest.umi.com.html/.

May, D.R. \& Pauli, K.P. 2002. The Role of Moral Intensity in Ethical Decision Making. Business \& Society, 41(1), 84-117.

McLain, D.A. \& Keenan, J.P. 1999. Risk, Information, and the Decision about Response to Wrongdoing in an Organization. Journal of Business Ethics, 19, 255-271.

Mendonca, M. 2001. Preparing for Ethical Leadership in Organizations. Canadian Journal of Administrative Science, 18 (5), 266276.

Near, J.P. \& Miceli, M.P. 1985. Organizational Dissidence: The Case of Whistle-Blowing. Journal of Business Ethics, 4(1), 1-16.
O'Fallon, M.J. \& Butterfield, K.D. 2005. A Review of the Empirical Ethical Decisionmaking Literature: 1996-2003. Journal of Business Ethics, 59, 375-413.

Rocha, E. \& Kleiner, B.H. 2005. To Blow or Not to Blow the Whistle? That is the Question. Management Research News, 28(11/12), 80-87.

Rothwell, G.R. \& Baldwin, J.N. 2007. Ethical Climate Theory, Whistle-Blowing, and the Code of Silence in Police Agencies in the State of Georgia. Journal of Business Ethics, 70(4), 341-361.

Shawver, T. 2011. The Effects of Moral Intensity on Whistleblowing Behaviors of Accounting Professionals. Journal of Forensic and Investigative Accounting, 3(2), 162-190.

Sholihin, M. \& Ratmono, D. 2013. Analisis SEM-PLS dengan WarpPLS 3.0. Yogyakarta: Andi Offset.

Susmanschi, G. 2012. Internal Audit and Whistle-Blowing. Economics, Management, and Financial Markets, 7(4), 415-421.

Tjahjono, S. 2013. Business Crimes and Ethics: Konsep dan Studi Kasus Fraud Di Indonesia dan Globa. Yogyakarta: ANDI.

Trevino, L.K. 1986. Ethical Decision Making in Organizations: A Person-Situation Interactionist Model. Academy of Management Review, 11, 601-617.

Victor, B. \& Cullen, J.B. 1988. The Organizational Bases of Ethical Work Climate. Administrative Science Quarterly, 33 (5), 101-125.

Zakaria, M. 2015. Antecedent Factors of Whistleblowing in Organizations. Procedia Economics and Finance, Vol. 28, No. 1, pp. 230-234. 